\title{
Spatial variation in demography of an estuarine teleost: implications for population and fishery assessments
}

\author{
Charles A. Gray ${ }^{1,2, *}$ \\ ${ }^{1}$ WildFish Research, Grays Point, Sydney, NSW 2232, Australia \\ ${ }^{2}$ Biological, Earth and Environmental Sciences, University of New South Wales, Sydney, NSW 2052, Australia
}

\begin{abstract}
Length- and age-based information is used to assess the exploitation status of harvested populations of fish worldwide. This study examined variability in length-at-age, length and age compositions and derived demographic parameters of Acanthopagrus australis (Sparidae) captured in beach seines in 3 estuaries across 5 yr. The method of ageing fish by counting opaque growth zones on sagittal otoliths was validated by field and aquaria studies. Length-at-age relationships varied according to gender, age class and estuary. Females older than 3 yr had a significantly greater mean length-at-age than males, and this was consistent across all estuaries. For both genders, mean length-at-age of fish older than 4 yr was greatest in the southernmost estuary, and least in the northernmost estuary, suggesting differential growth dynamics among estuaries. Observed longevity differed among estuaries, ranging from 14 to 22 yr. Variations in length composition of retained catches were subtler than those for age composition. The average age of fish in catches varied among estuaries from 4.2-5.1 yr to 6.8-8.2 yr even though fish within $5 \mathrm{~cm}$ of the minimum legal length dominated catches in all estuaries. Estimates of total and fishing mortality varied 3-fold among estuaries, with fishing mortality exceeding natural mortality. Variability in demographic characteristics was generally greater among estuaries than among years within each estuary. These results show that the population demographics and ensuing assessments should not be extrapolated across estuaries or from one estuary to the entire A. australis population. Length is a poor predictor of age and future sampling of populations must be age-based and stratified to account for estuary-specific variation in demography. Failure to account for such variability could confound assessments and management deliberations necessary for determining the most appropriate harvest and conservation strategies for such species.
\end{abstract}

KEY WORDS: Sparidae $\cdot$ Otolith $\cdot$ Ageing $\cdot$ Mortality $\cdot$ Sampling design $\cdot$ Demographic analysis · Fishery assessment

\section{INTRODUCTION}

Length- and age-based information provide some of the most important data on life history characteristics used to assess the exploitation status of harvested populations of fish and to examine the appropriateness of different fishery and conservation management strategies (Hilborn \& Walters 1992, Lai et al. 1996, Quinn \& Deriso 1999, Babcock et al. 2013). In particular, demographic parameters including rates

${ }^{*}$ Corresponding author:

charles.gray@wildfishresearch.com.au of growth, longevity and mortality derived from length- and age-based data are routinely incorporated into population and fishery assessment models (Ricker 1975, Quinn \& Deriso 1999, Patterson et al. 2001, Marriott et al. 2011). Knowledge of temporal and spatial changes in such demographic characteristics along with the length and age compositions of populations, including the harvested component, can help determine not only fishery-associated impacts, but also other anthropogenic and environmental per-

() The author 2015. Open Access under Creative Commons by Attribution Licence. Use, distribution and reproduction are unrestricted. Authors and original publication must be credited. 
turbations on populations (Walters \& Martell 2004, Begg et al. 2005, Williams et al. 2009).

Relationships between length-at-age and demographic characteristics of fish are known to vary over a hierarchy of spatial scales (Gust et al. 2002, Sinclair et al. 2002, Choat \& Robertson 2002, Williams et al. 2003). For example, some tropical reef-associated fish display differing rates of growth, longevity and age characteristics across spatial scales ranging from among localized clusters of patch reefs within a reef system to among reef systems across broad geographic regions (Newman et al. 1996, Meekan et al. 2001, Williams et al. 2003, 2007, Ruttenberg et al. 2005). Similarly, some estuarine-associated teleosts display widely differing growth and demographic parameters among estuaries of differing geomorphic and environmental conditions (Sarre \& Potter 2000, Bedee et al. 2002, Walsh et al. 2010). Moreover, latitudinal gradients in demographic characteristics of teleosts distributed over wide geographic distances are common (Vila-Gispert et al. 2002, Heibo et al. 2005, Lombardi-Carlson et al. 2008, Sala-Bozano \& Mariani 2011, Stocks et al. 2014). The extent of spatial variations in length-at-age and demography among populations can vary temporally, depending on rates of immigration and emigration (Sinclair et al. 2002, Williams et al. 2007).

Such variations in length-at-age can affect determinations of age compositions and rates of mortality and exploitation for establishing appropriate harvest and conservation strategies of exploited species (Newman et al. 2000, Campana 2001, Sinclair et al. 2002, Williams et al. 2007). It is imperative that species-specific levels of plasticity in length-at-age relationships and age-based parameter derivations of demographic characteristics be understood and incorporated into sampling designs and monitoring strategies (Williams et al. 2003). This includes the fishery-dependent sampling of the length and age compositions of the retained component of commercial and recreational catches (i.e. landings) of exploited species; a standard practice used by many fisheries agencies to obtain species-specific demographic information for monitoring and assessment purposes (Doubleday \& Rivard 1983, Gray et al. 2002, Stewart \& Hughes 2009, Marriott et al. 2011). This is particularly pertinent for species distributed over wide geographic expanses and captured across different fishery sectors. Failure to incorporate such information could potentially confound population assessments and subsequent management decisions.

This study investigates variability in the length-atage and age-derived demographic parameters of the harvested teleost Acanthopagrus australis (Sparidae). The Sparidae is a diverse family of fish exploited in fisheries in tropical and temperate waters worldwide (Gonçalves et al. 2003, Grandcourt et al. 2004, Pajuelo \& Lorenzo 2004, Vitale et al. 2011). A. australis occupies various habitats in estuaries and coastal waters across 20 degrees of latitude $\left(19-30^{\circ} \mathrm{S}\right.$; $\sim 2200 \mathrm{~km}$ ) along the east coast of Australia (Kailola et al. 1993, Gray et al. 1996, Kingsford 2002). It is a generalist carnivore (Bell et al. 1984) and is one of the most sought after fish species harvested by commercial, recreational and indigenous fishers in estuaries, with reported total harvests estimated to be around 1500 to 2000 tonnes per annum (Henry \& Lyle 2003, Rowling et al. 2010). The species is captured commercially using several active and passive gears, including beach seines, trawls, traps and gillnets across various fishery sectors. Hermaphroditism has been observed in the species (Pollock 1985), but the age and proportions of fish that change sex throughout the species range have not been quantified. Patterns of juvenile growth (Worthington et al. 1992, Griffiths 2001) and that of adults (combined across genders) in the species' northern range (Pollock 1982) have been partially described. There is a lack of information, however, concerning the extent of plasticity in length-at-age and growth characteristics of the species across estuaries and throughout its distribution. Moreover, spatial variability in demographic characteristics, including length and age compositions and rates of longevity and mortality, has not been investigated. Such information is required for incorporation into population and fisheries assessments of the species and for determining appropriate future sampling strategies.

In this study, retained commercial catches of $A$. australis taken in beach seines were sampled across 3 estuaries for $5 \mathrm{yr}$ to assess spatial and temporal variability in key demographic parameters. The study also incorporated field- and aquaria-based validations of counting opaque growth zones on sectioned otoliths as an ageing protocol. The results are discussed in terms of the ecology of the species and fishery assessment programs.

\section{MATERIALS AND METHODS}

\section{Sampling and study estuaries}

Retained commercial catches of Acanthopagrus australis taken from beach seines in 3 estuaries, Clarence River (CR, $\left.153^{\circ} 37^{\prime} \mathrm{E}, 2^{\circ} 43^{\prime} \mathrm{S}\right)$, Lake 
Macquarie (LM, $151^{\circ} 36^{\prime} \mathrm{E}, 33^{\circ} 08^{\prime} \mathrm{S}$ ) and St Georges Basin (SGB, $\left.150^{\circ} 59^{\prime} \mathrm{E}, 35^{\circ} 18^{\prime} \mathrm{S}\right)$, were sampled for length and age composition between February and July each year between 1995 and 1999. Whole catches or random sub-samples of whole catches landed on each of 15-20 sampling days per estuary and year were measured (nearest $0.5 \mathrm{~cm}$ below the fork length, FL). Because sampling was restricted to retained commercial catches, few fish below the minimum legal total length (MLL) of $25 \mathrm{~cm}(=22.5 \mathrm{~cm}$ FL) were examined. Sagittal otoliths were collected from random sub-samples of retained catches from each estuary and no more than 30 otolith pairs were collected from any one catch. Sampling was done during this time period each year as it generally coincided with greatest levels of commercial harvests, and pilot studies indicated that opaque growth zones were not deposited during this time. Between 200 and 600 otoliths were collected from catches from each estuary in each year. Each sampled fish was measured (FL) and sexed, and extracted otoliths were cleaned and stored until processing in the laboratory.

The beach seines used in each estuary had similar mesh dimensions and selectivity characteristics (Gray \& Kennelly 2003, Broadhurst et al. 2007), with regulations prescribing that mesh sizes in the cod-end be between 30 and $50 \mathrm{~mm}$, the bunt $\geq 50 \mathrm{~mm}$, and the wings $\geq 80 \mathrm{~mm}$. In LM and SGB, nets had a maximum headline length of $1000 \mathrm{~m}$ with a further $1000 \mathrm{~m}$ of hauling rope on each end, whereas in $\mathrm{CR}$, nets had a maximum headline length of $375 \mathrm{~m}$. Beach-seine nets were generally set in a semi-circular configuration from small $(<6 \mathrm{~m})$ boats and hauled back towards the shore by hand or using small winches (Gray \& Kennelly 2003).

The 3 study estuaries differed in their configurations, waterway areas, catchment sizes and surrounding habitats. CR is one of the largest coastal rivers of eastern Australia, having a length of approximately $250 \mathrm{~km}$ and a waterway area and catchment size of 89 and $22400 \mathrm{~km}^{2}$, respectively (www.dnr. nsw.gov.au/estuaries/inventory). CR has considerable freshwater input, extensive mangrove and seagrass stands, is surrounded by considerable agricultural land and supports one of the largest estuarine commercial fisheries in Australia. In contrast, both LM and SGB are shallow barrier estuaries (coastal lagoons) with little riverine input and constricted entrances to the sea. Nevertheless, LM is one of the largest coastal lakes in Australia, having a waterway area and catchment size of 120 and $700 \mathrm{~km}^{2}$, respectively. It has extensive coverage of seagrass, supports significant fisheries and is mostly surrounded by urban environments. SGB is much smaller, having a waterway area and catchment size of 39 and $407 \mathrm{~km}^{2}$, respectively, and is surrounded by a mix of urban and modified landscapes. The oceanic distance between CR and LM is approximately $500 \mathrm{~km}$, and between LM and SGB $300 \mathrm{~km}$. Throughout the sampling period, reported commercial harvests (tonnes per annum) of $A$. australis ranged between 21 to $47 \mathrm{t}$ in $\mathrm{CR}, 13$ to $46 \mathrm{t}$ in $\mathrm{LM}$ and 8 to $21 \mathrm{t}$ in SGB.

\section{Age determination and validation}

Sectioned sagittal otoliths were used to estimate the age of $A$. australis as preliminary examinations identified that whole otoliths were harder to read than thin sections, particularly for older fish, because of the stacking of growth zones near the otolith margin, a feature common to other Sparidae (Smale \& Punt 1991, Buxton 1993).

One sagitta from each sampled fish was embedded in clear resin and sectioned $(0.25-0.30 \mathrm{~mm})$ in a transverse plane through the focus using a low-speed saw fitted with 2 diamond blades. Both sides of the resulting section were polished on lapping film $(0.09 \mathrm{~mm})$, after which each section was mounted on a glass slide and viewed under a binocular microscope with reflected light against a black background. Otolith sections displayed a pattern of narrow opaque (light) and broad translucent (dark) zones. Assignment of age was based on counts of completed opaque zones between the focus to the outer edge of the otolith along the line of the sulcus. Sections were interpreted independently by 2 people without knowledge of the length or sex of the fish, or the date and location of capture. A third reader interpreted all discrepancies and a final age was based on consensus among readers. Assignment of age and year class was consistent across years and estuaries because all samples were collected within the same 6 mo period each year. Further, there was no need to adjust assigned ages based on the time of collection of samples as the formation and completion of opaque growth zones occurred outside the sampling period (see 'Results: Ageing and age validation').

Marginal increment (MI) analysis was used to determine the periodicity of formation of opaque zones on sagittal otoliths. At least 30 A. australis were sampled from catches each month between November 1996 and 1997 from the CR and processed for age determination as described above. Sections were examined, assigned an age and an otolith margin condition of either opaque or translucent. An image 
processor was used to measure the distance from the otolith focus to each successive opaque zone and to the otolith edge. All measurements were made along the dorsal edge of the sulcus to the nearest $0.05 \mathrm{~mm}$. The MI was expressed as: (1) the distance from the first opaque zone to the otolith edge as a proportion of the distance from the focus to the first opaque zone for fish with one opaque zone, and (2) the distance from the most recently completed opaque zone to the otolith edge as a proportion of the last completed increment for fish with 2 or more opaque zones. Mean $( \pm 1 \mathrm{SE}) \mathrm{MI}$ was calculated for each separate age group and for all ages combined for each month.

Aquaria-held juvenile $A$. australis were used to validate the occurrence and timing of deposition of the 1st opaque growth zone on otoliths. A total of 165 wild $A$. australis ranging between 5.5 and $17.5 \mathrm{~cm} \mathrm{FL}$ were collected using research seine nets from the Port Hacking estuary $\left(151^{\circ} 13^{\prime} \mathrm{E}, 34^{\circ} 07^{\prime} \mathrm{S}\right)$ in March 1999. Upon capture, the fish were transported to the aquaria facility at the Cronulla Fisheries Research Centre (10 min boat trip). Here they were given a mild antibiotic bath (oxytetracycline [OTC] solution at $0.1 \mathrm{~g} \mathrm{l}^{-1}$ seawater) and transferred into a $5000 \mathrm{l}$ tank that had flow-through seawater (directly pumped from Port Hacking) and was maintained at near ambient water and air temperatures and exposed to natural diurnal cycles. Two weeks following capture, all $A$. australis were given a course of medicated feed containing OTC (100 g) over $10 \mathrm{~d}$. This procedure successfully marked the otoliths of $88 \%$ of individuals, with the OTC mark being visible on sections of otoliths using a UV light source. For the duration of captivity, fish were monitored and fed high-protein fish pellets once a day.

Every 8 wk between June 1999 and March 2000, 10 individuals were sampled from the tank, euthanized and had their otoliths removed and processed for ageing as described above. The distance from the core and the OTC mark to the otolith edge was measured and, if present, the distance from the otolith core to the first opaque zone was also measured. All measurements were made on the outer side of the sulcus, on the ventral lobe. The experiment was terminated in March 2000 as all remaining fish died from a disease.

\section{Length-at-age relationships and growth}

A 3-factor ANOVA was used to test whether the length-at-age of $A$. australis differed according to gender, age class (2-10 yr) and estuary (all fixed fac- tors). A separate 2-factor ANOVA was used to test for differences in length-at-age according to gender and age class (2-14 yr) in CR. Multiple comparisons were used to determine differences among specific means for factors identified as significant in the ANOVA. Mean length-at-age of each gender of A. australis from each estuary was determined and graphed. Growth could not be adequately modeled and von Bertalanffy growth parameters could not be determined due to the absence of juveniles and the truncation of length data at the minimum legal FL. Therefore, gender- and estuary-related differences in mean length-at-age were used to infer patterns of growth and longevity.

\section{Length and age compositions}

The length and age compositions of retained catches of $A$. australis were generated for each estuary and year. The age compositions of populations were calculated by applying separate estuary- and yearspecific age-length keys to the relevant length composition data for each estuary and year (Lai et al. 1996). The mean length and age of retained catches were determined for each estuary and year. A 2factor PERMANOVA (Anderson 2001) was used to determine whether the length and age compositions of populations differed among estuaries (using years as replicates) and years (using estuaries as replicates). The percent contribution of fish in each length and age class was used to classify populations using the Bray Curtis dissimilarity matrices with results displayed in 2-dimensional MDS ordination plots (Clarke 1993). SIMPER analyses were used to identify which length and age classes contributed most towards differences in compositions among estuaries.

\section{Mortality and exploitation}

Estimates of the instantaneous rate of total mortality $(Z)$ were calculated for each estuary and year using the age-based catch curve method (Ricker 1975). For each analysis, it was assumed that the most abundant age class in each sample (between 3 and $9 \mathrm{yr}$; see Results) was fully recruited to the sampled population. $\mathrm{SE}$ and $\mathrm{R}^{2}$ values were calculated for each regression. Natural mortality $(M)$ was determined using the method of Hoenig (1983), based on (1) the observed maximum attained age of $22 \mathrm{yr}$ across the study (see 'Results'), and (2) the observed maximum attained age in each separate estuary. 
Fishing mortality $(F)$ was estimated by subtracting $M$ from $Z$, providing an estimate of exploitation rate $(E)$ $(E=F / Z)$ for each estuary and year.

\section{RESULTS}

\section{Ageing and age validation}

A total of 4992 Acanthopagrus australis were aged, with the overall agreement between the 2 readers being $88.3 \%$ and for $\pm 1 \mathrm{yr}, 98.7 \%$.

The mean MI value of wild-caught $A$. australis in CR was high in November and decreased to a low in February, after which it increased to attain a maximum in September and October (Fig. 1A). The greatest proportion of otoliths with opaque edges occurred in October, after which proportions decreased to February and remained relatively low until May, after which they increased. These results indicate that opaque growth zones were deposited once per annum and completed between November and February.

For aquaria-held juvenile $A$. australis, the OTC stain in sectioned otoliths was visible under UV light for 145 individuals. The first opaque zone deposited after the OTC stain was visible between August and October, after which no further opaque zones were observed when the experiment ended in March 2000 (Fig. 1B). The distance from the otolith core to the first opaque zone was $0.48( \pm 0.02 \mathrm{SE}) \mathrm{mm}$.

\section{Length-at-age relationships, growth and longevity}

FL was a poor predictor of age as length-at-age was highly variable across genders and estuaries (Fig. 2). The mean length-at-age of A. australis differed significantly according to the 3 main factors of gender, age class and estuary (ANOVA, $p<0.0001$ in all cases) and the interactive effects of gender and age class (ANOVA, df =8,4462, $F=7.562, \mathrm{p}<0.0001$ ) and age class and estuary (ANOVA, df = 16, 4462, $F=15.168, \mathrm{p}<0.0001)$. Multiple comparisons identified that the mean length-at-age did not differ significantly between genders for age classes 2, 3 and 4, but it was significantly greater in females than males for age classes 5 to 9 (Fig. 3). This indicated that females grew to an overall greater FL than males. The mean length-at-age of each gender did not differ significantly among age classes 2 to 4 (most likely due to the truncation of fish at the MLL and the subsequent under-sampling of small individuals in these
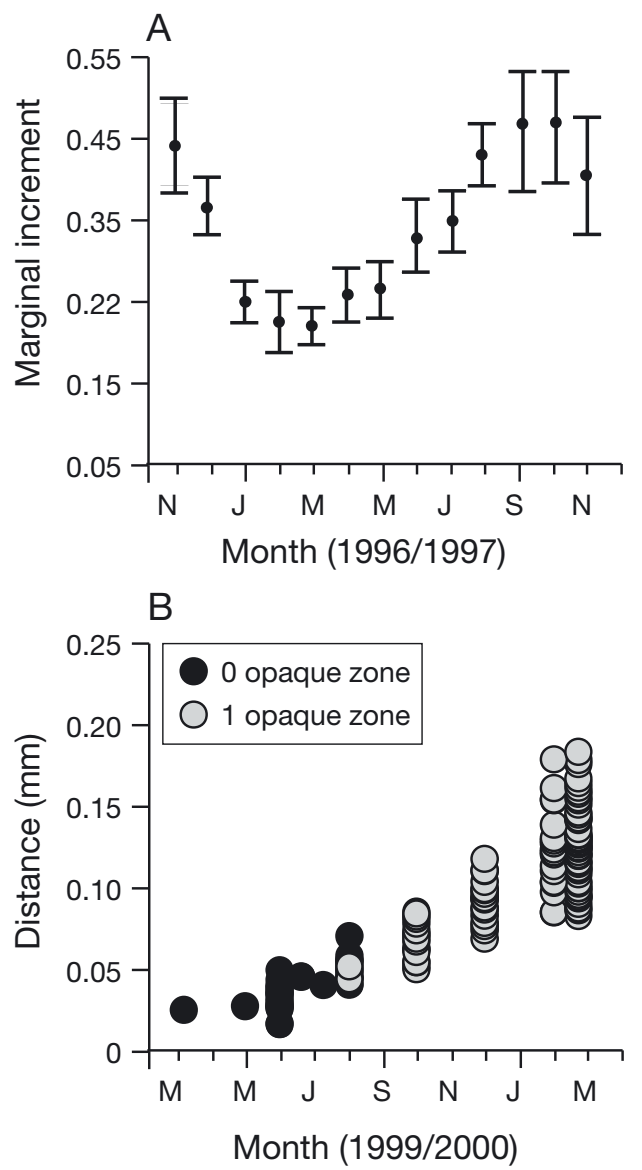

Fig. 1. (A) Mean ( \pm 1 SE) marginal increment for wild-caught Acanthopagrus australis captured in the Clarence River between November 1996 and November 1997. (B) Distances (mm) from the oxytetracycline mark to the otolith edge for $A$. australis stained in March 1999 and kept in captivity, and the number of opaque zones observed on the otolith of each sampled fish. The otoliths of all fish had 0 opaque zones until August, after which most fish otoliths had 1 opaque zone

age classes; Fig. 2), but it generally increased thereafter with each successive age class (Fig. 3). The multiple comparisons also identified that the mean length-at-age did not differ among estuaries for age classes 2 and 3, but was significantly greater in SGB than both LM and CR for age classes 4 to 9 (Fig. 3). For age classes 6 to 9, mean length-at-age was also greater in LM than CR. This trend was evident across both genders, indicating that the growth dynamics of A. australis varied spatially (Fig. 3).

The largest $A$. australis sampled was $42 \mathrm{~cm}$ FL (age $6 \mathrm{yr}$ ) and the oldest was $22 \mathrm{yr}(36 \mathrm{~cm} \mathrm{FL),} \mathrm{both}$ from CR. Estimated longevity varied among estuaries and genders, with the oldest female and male sampled in each estuary being 22 and $18 \mathrm{yr}$ in CR, 14 and $14 \mathrm{yr}$ in LM, and 21 and $19 \mathrm{yr}$ in SGB, respectively. 

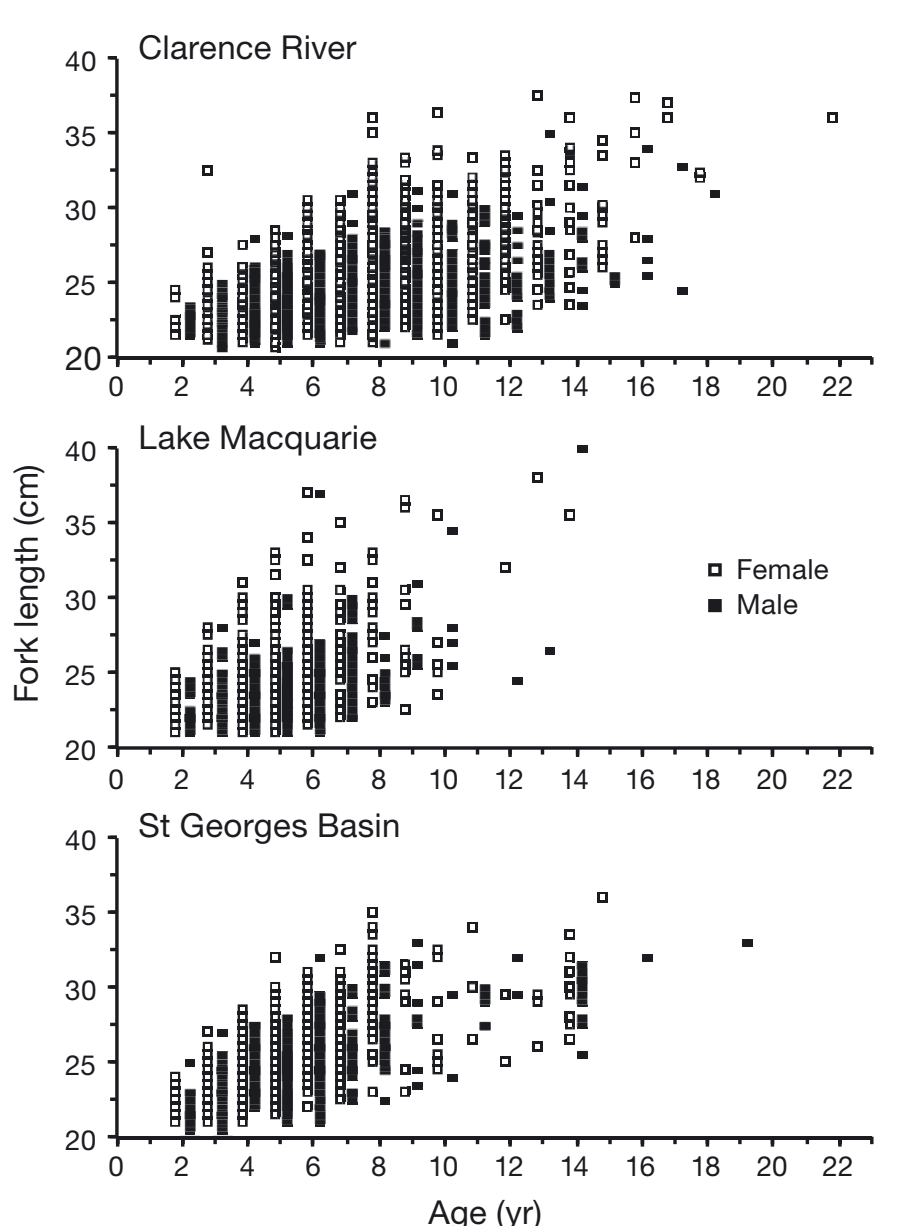

Fig. 2. Length-at-age of sampled female and male Acanthopagrus australis retained in commercial beach-seine catches in the Clarence River, Lake Macquarie and St Georges Basin. Data are combined across sampling years

\section{Length and age compositions}

A. australis retained from commercial beach-seine catches ranged between 20 and $42 \mathrm{~cm}$ FL, but catches in each estuary were primarily dominated by individuals between 22 and $25 \mathrm{~cm}$ FL (Figs. 4-6). The mean lengths of retained $A$. australis were greater in CR (24.73 to $25.35 \mathrm{~cm} \mathrm{FL)} \mathrm{and} \mathrm{SGB} \mathrm{(24.28} \mathrm{to} 25.20 \mathrm{~cm}$ FL) than LM (23.81 to $24.07 \mathrm{~cm}$ FL). PERMANOVA indicated that the length compositions differed significantly among estuaries ( $\mathrm{df}=2,10, F=10.03, \mathrm{p}<0.01)$, with the pairwise comparisons indicating that LM was significantly different from CR and SGB $(\mathrm{p}<0.05$ in both cases), but CR and SGB did not significantly differ ( $p>0.05$; Fig. 7). The MDS indicated that the retained catches in SGB in 1996 and 1997 were most similar to those in CR (Fig. 7). There was no significant ( $p>0.05$ ) global effect of year (pooled across estuaries) on length compositions.
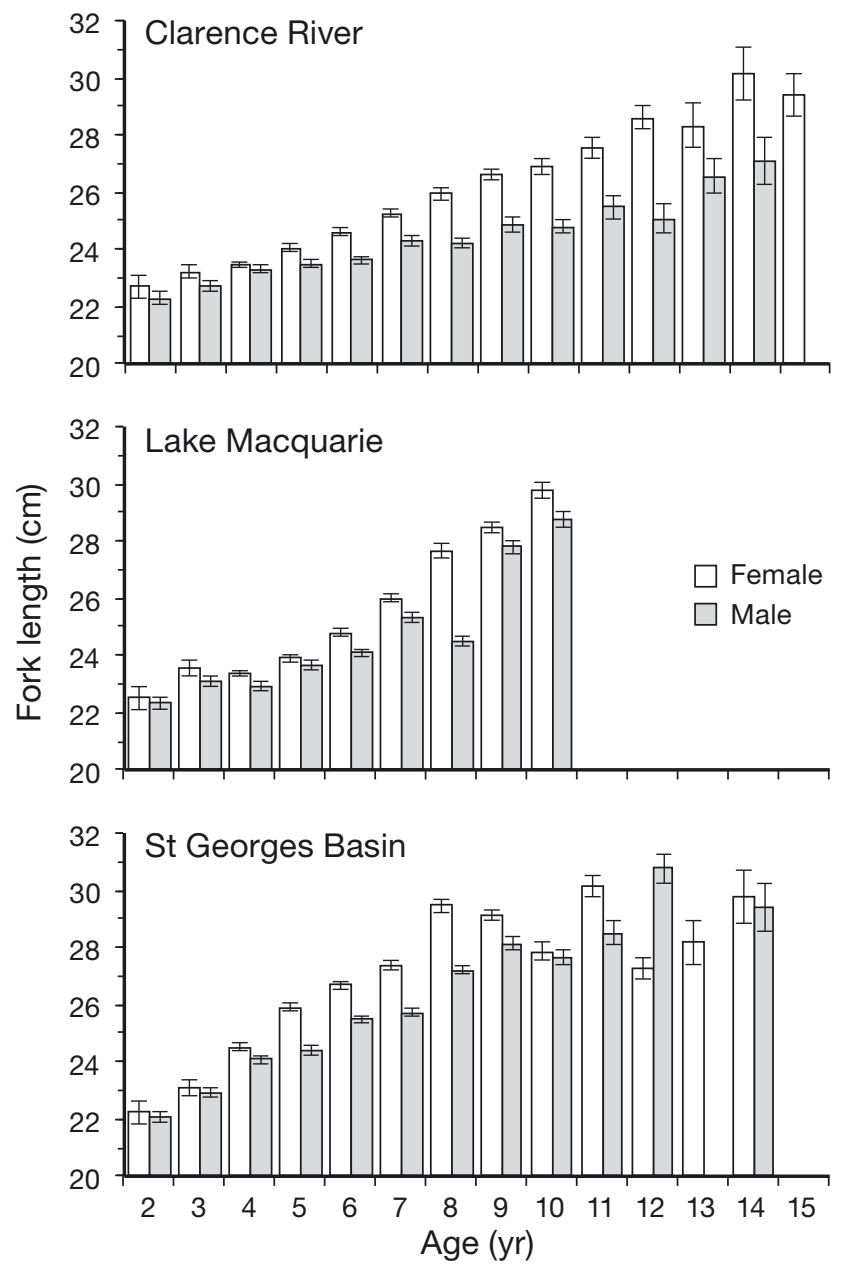

Fig. 3. Mean ( $\pm 1 \mathrm{SE}$ ) length-at-age of sampled female and male Acanthopagrus australis retained in commercial beachseine catches in the Clarence River, Lake Macquarie and St Georges Basin. Data are combined across sampling years

The retained beach-seine catches contained $A$. australis aged between 2 and $22 \mathrm{yr}$, although individuals less than $10 \mathrm{yr}$ were most predominant (Figs. 4-6). The mean age of $A$. australis in retained catches was approximately 2 to $3 \mathrm{yr}$ greater in CR (range 6.80 to $8.18 \mathrm{yr}$ ) than LM (range 4.49 to $5.22 \mathrm{yr}$ ) and SGB (range 4.23 to $5.05 \mathrm{yr}$ ). The age compositions differed significantly among estuaries (PERMANOVA, df $=2,10, F=14.90, \mathrm{p}<0.001)$, with the pairwise comparisons identifying that each estuary differed from all others ( $p<0.01$ in all cases). SIMPER analysis indicated that these differences were mostly due to the greater occurrence of the older age classes in CR compared with LM and SGB. Twenty percent of fish were 10 years or older in CR, whereas this value was $1.1 \%$ in LM and $3.2 \%$ in SGB. The age compositions did not differ significantly $(p>0.05)$ by year (pooled across estuaries). The age compositions 


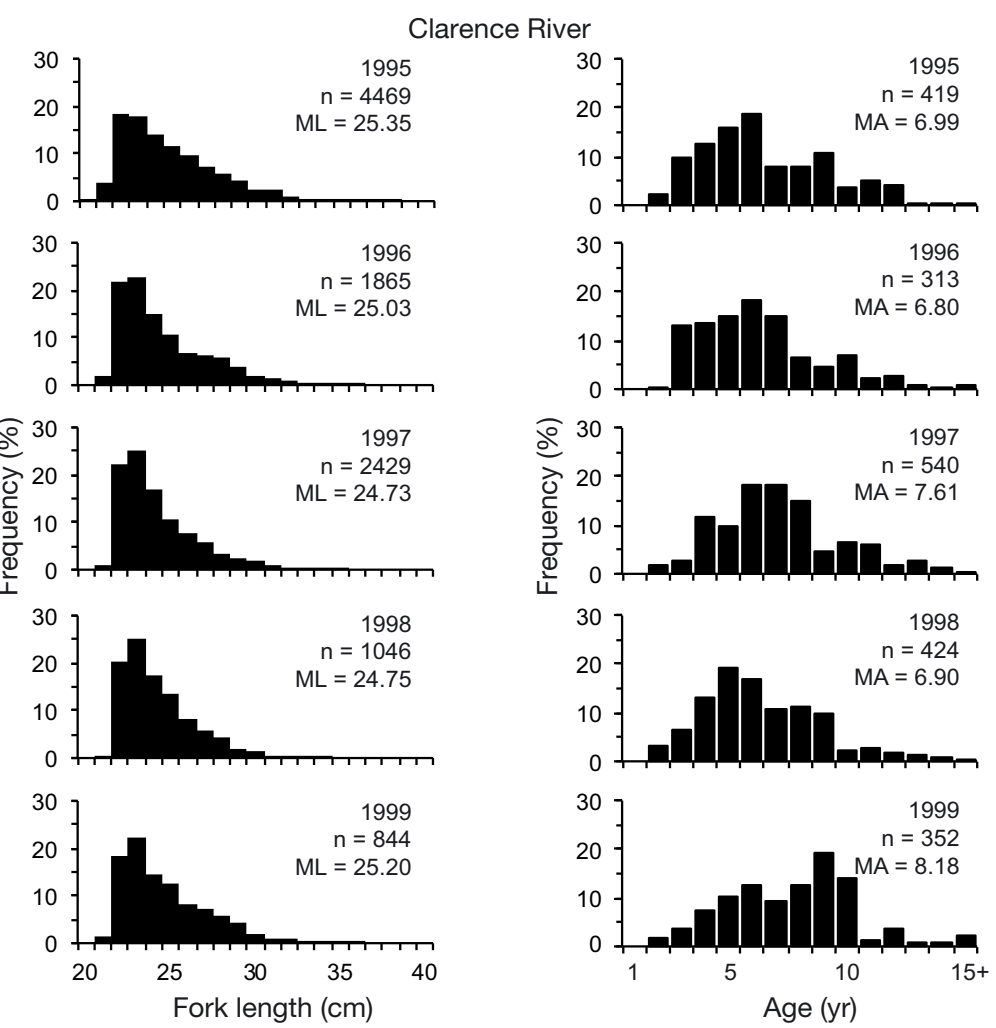

Fig. 4. Length and age compositions of Acanthopagrus australis retained in commercial beach-seine catches in the Clarence River between 1995 and 1999. n: number of lengths measured and number of fish aged; ML: mean length (cm fork length); MA: mean age (yr)

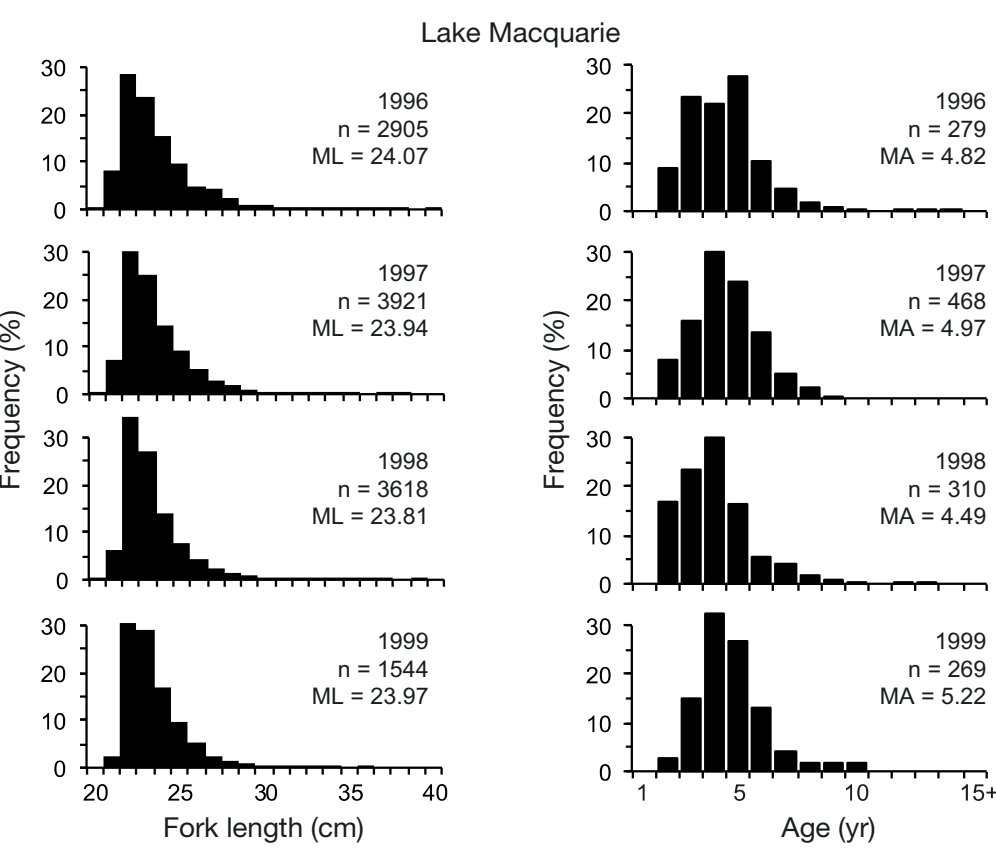

Fig. 5. Length and age compositions of Acanthopagrus australis retained in commercial beach-seine catches in Lake Macquarie between 1996 and 1999. n: number of lengths measured and number of fish aged; ML: mean length (cm fork length); MA: mean age (yr) in LM were least variable across years compared with both CR and SGB (Fig. 7). The annual progression of some age classes in $\mathrm{CR}$ could be followed across the annual samples; notably, the relatively strong 1988 and weak 1989 year classes could be tracked as age 6 and age 7 in 1995, up to age 10 and age 11 in 1999 (Fig. 4). The progression of specific age classes could not be followed in either LM or SGB.

\section{Mortality}

Estimates of $Z$ ranged between 0.41 and 1.17 depending on the estuary and year, and were generally lowest in $\mathrm{CR}$ and greatest in LM (Table 1, Fig. 8). Because of differing age compositions, the age range used in each catch curve analysis varied among estuaries, and in 2 instances between years within an estuary. In CR and SGB, $Z$ was relatively consistent among years, varying between 0.41 and 0.54 in CR and 0.62 and 0.65 in SGB. The precision of $Z$ varied among estuaries and years, with the $\mathrm{R}^{2}$ value generally being least in $\mathrm{CR}$. Based on the maximum aged A. australis in samples being $22 \mathrm{yr}, M$ was determined to be 0.19 , with corresponding estimates of $F$ ranging from 0.22 to 0.98 , and $E$ from 0.53 to 0.84 (Table 1). Both $F$ and $E$ were generally least in CR and greatest in LM using $M=0.19$. When the actual observed maximum ages in each separate estuary were used in calculations, $F$ and $E$ for LM were greatly reduced so they more closely resembled those values obtained in $\mathrm{CR}$ and SGB (Table 1). Estimates of $F$ and $E$ were similar among years in CR and SGB, whereas they were more variable in LM. Except for LM in 1999, all estimates of $F$ were $>M$.

\section{DISCUSSION}

\section{Ageing}

It is essential that ageing techniques be validated (Beamish \& McFarlane 1983, Campana 2001). The MI analyses of wild-caught fish along with the aquaria-based study incorporated here identified that the opaque growth zones on sectioned otoliths of Acanthopagrus 
St Georges Basin

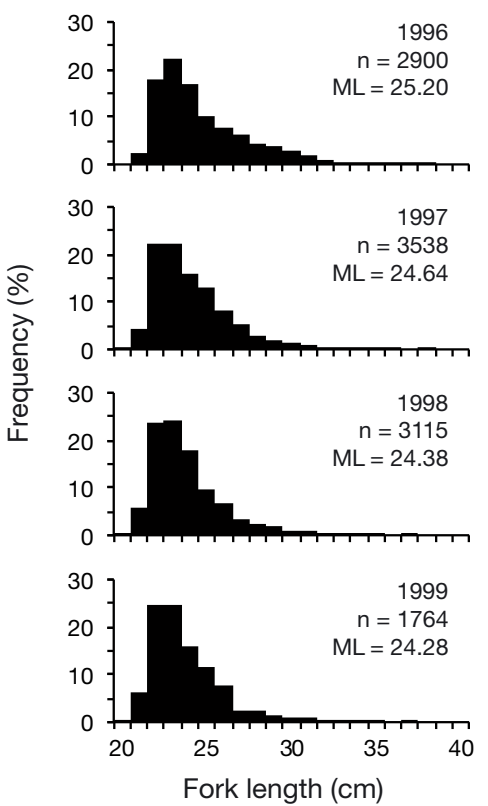

Fig. 6. Length and age compositions of Acanthopagrus australis retained in commercial beach-seine catches in St Georges Basin between 1996 and 1999. n: number of lengths measured and number of fish aged; ML: mean length (cm fork length); MA: mean age (yr)

australis were deposited annually. In further support of this, the annual progression of the 6 and 7 yr age classes in 1995 in CR could be followed across the $5 \mathrm{yr}$ of sampling to become the 10 and $11 \mathrm{yr}$ age classes in 1999, further indicating that the counted opaque growth zones were annuli. Moreover, in a separate study, the otoliths of several recaptured A. australis that had previously been injected with OTC and released into several estuaries displayed a general deposition of one opaque growth zone per year of liberty post-OTC marking (Ferrell 2000).

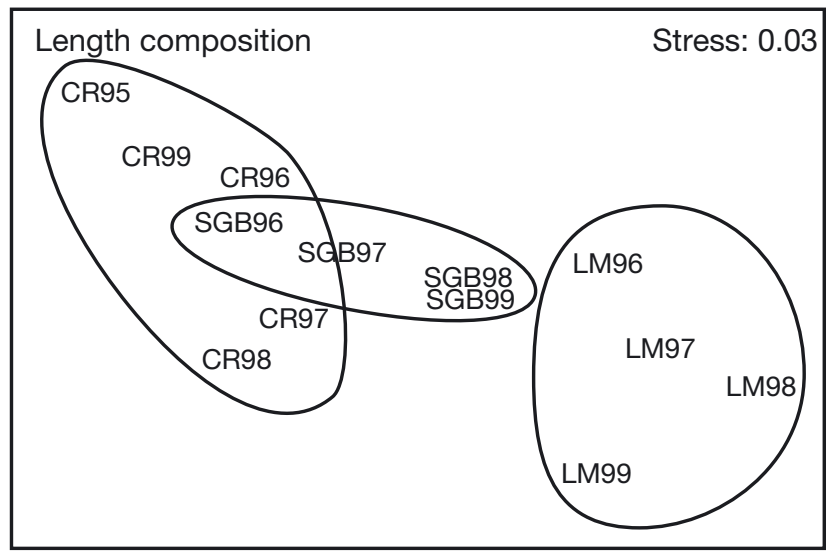

Fig. 7. Non-metric multidimensional scaling ordinations displaying relationships between length and age compositions of retained catches of Acanthopagrus australis taken from commercial beach seines in the Clarence River, Lake Macquarie and

St Georges Basin. CR: Clarence River; LM: Lake Macquarie; SGB: St Georges Basin; 95-99: 1995-1999

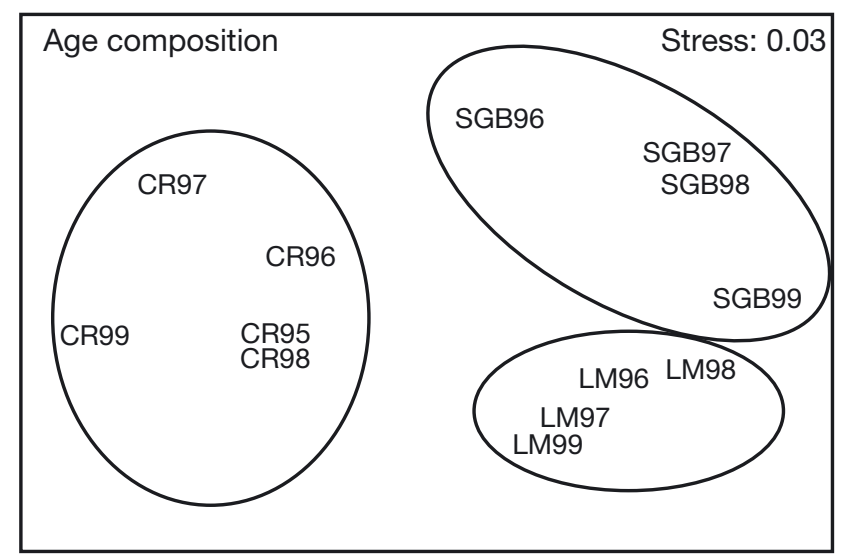

The spring-summer timing of opaque growth zone deposition on the otoliths of wild-caught and aquaria-held $A$. australis concurs with that of a diverse range of teleosts in southeastern Australia, including Platycephalus longispinis and $P$. richardsoni (Barnes et al. 2011), Liza argentea and Myxus elongatus (Kendall et al. 2009), Sillago maculata (Kendall \& Gray 2009) and Rhabdosargus sarba (Hughes et al. 2008). The data indicate that the 1st opaque zone in $A$. australis was first visible slightly earlier (August to October) than successive opaque zones in wild A. australis (September to February). This was probably due to the younger fish growing faster and therefore the opaque growth zone being observed slightly earlier (Smith \& Deguara 2003, Hughes et al. 2008). These broad results support the hypothesis that completion of opaque growth zone formation on the otoliths of fish in this region generally occurs over the spring to summer period, but the exact timing within this period can vary according to latitude and year (Gray et al. 2014, Stocks et al. 2014). Ageing of fish outside of this period can be done without the confounding problems of interpreting otolith edge condition for ascribing actual age (Fowler \& Short 1998, Kendall et al. 2009).

\section{Length-at-age, growth and longevity}

Because the data collected here were limited to legal length fish, the estimates of mean length-at-age for $A$. australis aged between 2 and 6 yr were proba- 
Table 1. Estimated instantaneous rates of total mortality $(Z)$ with corresponding $\mathrm{SE}$ and $\mathrm{R}^{2}$ values and the age range used in each catch curve analysis of age composition data from beach-seine catches of Acanthopagrus australis taken in each year in the Clarence River, Lake Macquarie and St Georges Basin. Estimated rates of natural $(M)$ and fishing $(F)$ mortality and exploitation $(E)$ are also shown. Calculations are based on the observed maximum age ( 22 yr) across all estuaries, or the observed maximum age in each separate estuary: 22 yr in Clarence River, 14 yr in Lake Macquarie and 21 yr in St Georges Basin

\begin{tabular}{|c|c|c|c|c|c|c|c|c|c|c|}
\hline \multirow{2}{*}{ Year } & \multirow{2}{*}{$\begin{array}{c}\text { Age range } \\
(\mathrm{yr})\end{array}$} & \multicolumn{3}{|c|}{ Catch curve } & \multicolumn{3}{|c|}{ All estuaries } & \multicolumn{3}{|c|}{ Separate estuaries } \\
\hline & & $Z$ & $\mathrm{SE}$ & $\mathrm{R}^{2}$ & $M$ & $F$ & $E$ & $M$ & $F$ & $E$ \\
\hline \multicolumn{11}{|c|}{ Clarence River } \\
\hline 1995 & $6-15$ & 0.54 & 0.09 & 0.81 & 0.19 & 0.35 & 0.65 & 0.19 & 0.35 & 0.65 \\
\hline 1996 & $6-15$ & 0.49 & 0.05 & 0.91 & 0.19 & 0.30 & 0.62 & 0.19 & 0.30 & 0.62 \\
\hline 1997 & $6-15$ & 0.47 & 0.08 & 0.81 & 0.19 & 0.28 & 0.60 & 0.19 & 0.28 & 0.60 \\
\hline 1998 & $6-15$ & 0.41 & 0.04 & 0.94 & 0.19 & 0.22 & 0.53 & 0.19 & 0.22 & 0.53 \\
\hline 1999 & $9-15$ & 0.53 & 0.15 & 0.72 & 0.19 & 0.34 & 0.64 & 0.19 & 0.34 & 0.64 \\
\hline \multicolumn{11}{|c|}{ Lake Macquarie } \\
\hline 1996 & $5-10$ & 1.17 & 0.13 & 0.95 & 0.19 & 0.98 & 0.84 & 0.30 & 0.87 & 0.74 \\
\hline 1997 & $4-10$ & 0.98 & 0.11 & 0.94 & 0.19 & 0.79 & 0.81 & 0.30 & 0.68 & 0.69 \\
\hline 1998 & $4-10$ & 0.81 & 0.05 & 0.98 & 0.19 & 0.62 & 0.76 & 0.30 & 0.51 & 0.63 \\
\hline 1999 & $4-10$ & 0.58 & 0.08 & 0.92 & 0.19 & 0.39 & 0.67 & 0.30 & 0.28 & 0.48 \\
\hline \multicolumn{11}{|c|}{ St Georges Basin } \\
\hline 1996 & $3-12$ & 0.63 & 0.10 & 0.83 & 0.19 & 0.44 & 0.70 & 0.20 & 0.43 & 0.68 \\
\hline 1997 & $3-12$ & 0.65 & 0.04 & 0.96 & 0.19 & 0.46 & 0.71 & 0.20 & 0.45 & 0.69 \\
\hline 1998 & $3-12$ & 0.63 & 0.05 & 0.96 & 0.19 & 0.44 & 0.70 & 0.20 & 0.43 & 0.68 \\
\hline 1999 & $3-12$ & 0.62 & 0.05 & 0.96 & 0.19 & 0.43 & 0.69 & 0.20 & 0.42 & 0.68 \\
\hline
\end{tabular}

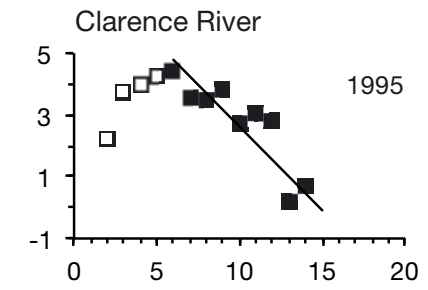

Fig. 8. Catch curves of retained Acanthopagrus australis catches taken from commercial beach seines in the Clarence River, Lake Macquarie and St Georges Basin. Filled squares included in catch curve calculation
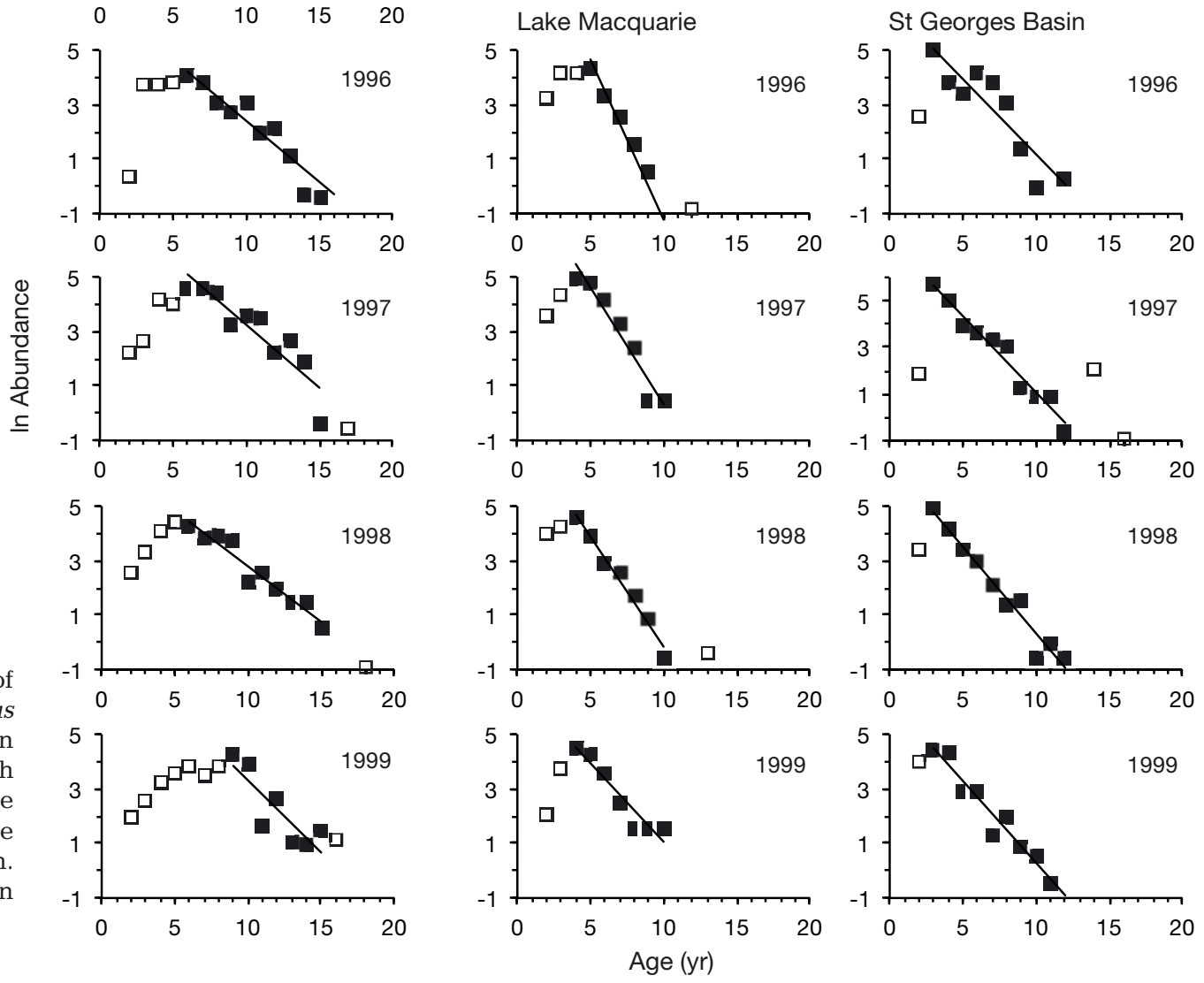
bly overestimated, with the fastest growing individuals in these age classes being selectively retained in catches each year. Inclusion of sub-legal length fish $(<22 \mathrm{~cm} \mathrm{FL})$ is required to ascertain the true mean length-at-age within these age classes and to determine growth trajectories across all life stages. Nevertheless, the data presented here indicate that $A$. australis has fast growth during the first $2 \mathrm{yr}$ of life, after which growth slows, most likely due to attainment of sexual maturity (see also Pollock 1982). These data also provide unique insights into the potential plasticity in length-at-age relationships and growth, and concomitant effects on population assessments of $A$. australis.

The length-at-age data demonstrated that $A$. australis has variable growth dynamics, with gender and estuary being significant contributors to such variation. Mean length-at-age was generally greater for females than for males for fish aged $4 \mathrm{yr}$ and older, and females also attained a greater observed overall FL than males (particularly in CR). These results suggest that females grew faster and attained greater FLs than males (a previous study on A. australis did not discriminate between genders; Pollock 1982). This result is consistent with reports on many other Sparidae (Morison et al. 1998, Pajuelo \& Lorenzo 2000, 2004, Pajuelo et al. 2006, Alós et al. 2010), but gender-related growth patterns in contrast to this are apparent within the family (Pajuelo \& Lorenzo 2003, Brouwer \& Griffiths 2004, Dulčić et al. 2011) and can be confounded due to the prevalence of protandric hermaphroditism displayed by several species, including A. australis (Pollock 1982, Buxton 1993, Pajuelo \& Lorenzo 2000, Abou-Seedo et al. 2003, Pajuelo et al. 2006). Further work is required to determine the levels and effects of hermaphroditism on sexspecific growth rates of $A$. australis.

Changes among year classes in mean length-atage indicated that growth of both genders was greatest in SGB and least in CR for fish 6 yr and older. Geographic (latitudinal) and estuary-related differences in length-at-age and patterns of growth are common among estuarine and coastal fish, including Sparidae (Sarre \& Potter 2000, Bedee et al. 2002, Benchalel \& Kara 2013, Stocks et al. 2104), and can be influenced by various biotic (e.g. genetics, food availability) and abiotic (e.g. ambient water temperatures, hydrography, freshwater flows) factors (Choat \& Robertson 2002, Sinclair et al. 2002, Williams et al. 2007). The marked differences in geomorphology and hydrography of the estuaries sampled (particularly between $\mathrm{CR}$ - a large river - and the other 2 estuaries, both coastal lagoons) and concomitant effects on productivity and trophic dynamics probably contributed to the observed differences among estuaries in length-at-age of $A$. australis. Nevertheless, the geographic patterns in length-at-age displayed here contrasted another teleost cohabitant, Girella tricuspidata, which displayed faster growth in CR than in other estuaries, including LM and SGB (Gray et al. 2010). Further, 2 mugilid species had greater mean lengths-at-age and growth in LM compared with SGB (Kendall et al. 2009). In a similar way, different species of coral reef fish display contrasting degrees of variability in demography among the same reefs (Williams et al. 2007). Although it was not possible to isolate the specific mechanisms responsible for driving the observed differences in mean length-at-age and growth of $A$. australis here, it is evident that such factors do not influence all teleost species within these estuaries in the same way.

The maximum age of $22 \mathrm{yr}$ for $A$. australis reported here was greater than the previous reports of 6 to 12 yr (Pollock 1982, Kailola et al. 1993). A total of 130 fish aged greater than 12 yr were sampled in the current study, which may have been due to the greater scale of sampling across several estuaries and years than in previous studies. Estimated longevity of $A$. australis was influenced by estuary, with fish not exceeding $14 \mathrm{yr}$ in LM, but attaining $21 \mathrm{yr}$ in SGB and $22 \mathrm{yr}$ in CR. Observed longevity did not differ greatly between genders (19 compared with $22 \mathrm{yr}$ for males and females, respectively), which is concordant with reports of other Sparidae (Sarre \& Potter 2000, Dulčić et al. 2011). Sparids display a diverse range of longevities, with the recorded maximum ages of some estuarine/coastal species elsewhere exceeding 40 yr (Horn 1986, Buxton \& Garratt 1990). It is possible that $A$. australis could potentially reach greater longevities than observed here, as it has been reported to reach lengths of $55 \mathrm{~cm}$ FL (Kailola et al. 1993). Fishing may have reduced the proportions of older fish in these populations, as reported for several other exploited fish species in eastern Australia (Silberschneider et al. 2009, Stewart 2011).

\section{Length and age compositions and mortality}

Variations in length composition of retained catches among estuaries were more subtle than variations in age composition, and were greatly influenced by the proportions of fish $>25 \mathrm{~cm}$ FL in catches. The mean lengths (and ages) of $A$. australis in retained catches were consistently greater in CR and SGB than in LM, with CR having a greater proportion of fish between 
25 and $30 \mathrm{~cm}$ FL than either LM or SGB. Despite these variations, A. australis within $5 \mathrm{~cm}$ FL of the MLL dominated the length compositions in all estuaries. This pattern has also been observed in the retained catches from other estuarine commercial fishing gears, including gillnets, traps and otter trawls (Gray et al. 2000, 2005, Gray 2002) and has been a feature of the length compositions of commercial landings (combined across gear types and estuaries) of $A$. australis sampled over the past $50 \mathrm{yr}$ (Fig. 9). Unfortunately, these historical length-based data do not provide any information on the underlying age compositions and age-based demographics of catches necessary for assessments. The length-at-age relationships, age compositions, longevity and mortality schedules of the species may have changed greatly during this time period even though the length distributions have remained relatively stable. As observed here, the age compositions of retained catches of $A$. australis can differ markedly even when corresponding length compositions differ little.

Several age classes contributed to the retained beach-seine catches, with the relative abundance and dominance of any particular year class varying among estuaries and, especially in $\mathrm{CR}$, among years. Recruitment of A. australis to the fishery most likely varied accordingly, and although the causative mechanisms of such recruitment variation could not be ascertained here, the large variation in length-atage of $A$. australis meant their age at legal length and subsequent entry to the fishery ranged from 2 to 10 yr. Such protracted recruitment to the fishery probably provides protection to individual age classes from over-harvesting and reduces the effects of strong and weak years of recruitment on fishery productivity. This directly contrasts the situation for another estuarine sparid, A. butcheri, in which the fishery is dependent on the episodic recruitment of a couple of strong year classes (Morison et al. 1998). These 2 species have different reproductive ecologies, with $A$. australis spawning in lower estuary and coastal environments and $A$. butcheri in the upper estuaries (Pollock 1985, Morison et al. 1998).

Because of the estuary-specific age compositions, estimates of mortality and exploitation varied greatly among estuaries, and for LM in particular were dependent on the maximum age used in calculations. Given the observed differential length-at-age dynamics of $A$. australis and that life-history traits are often correlated, it may be more prudent to use the observed maximum age in each separate estuary rather than a global maximum age in mortality calculations. Both $F$ and $E$ were reduced when this was done for
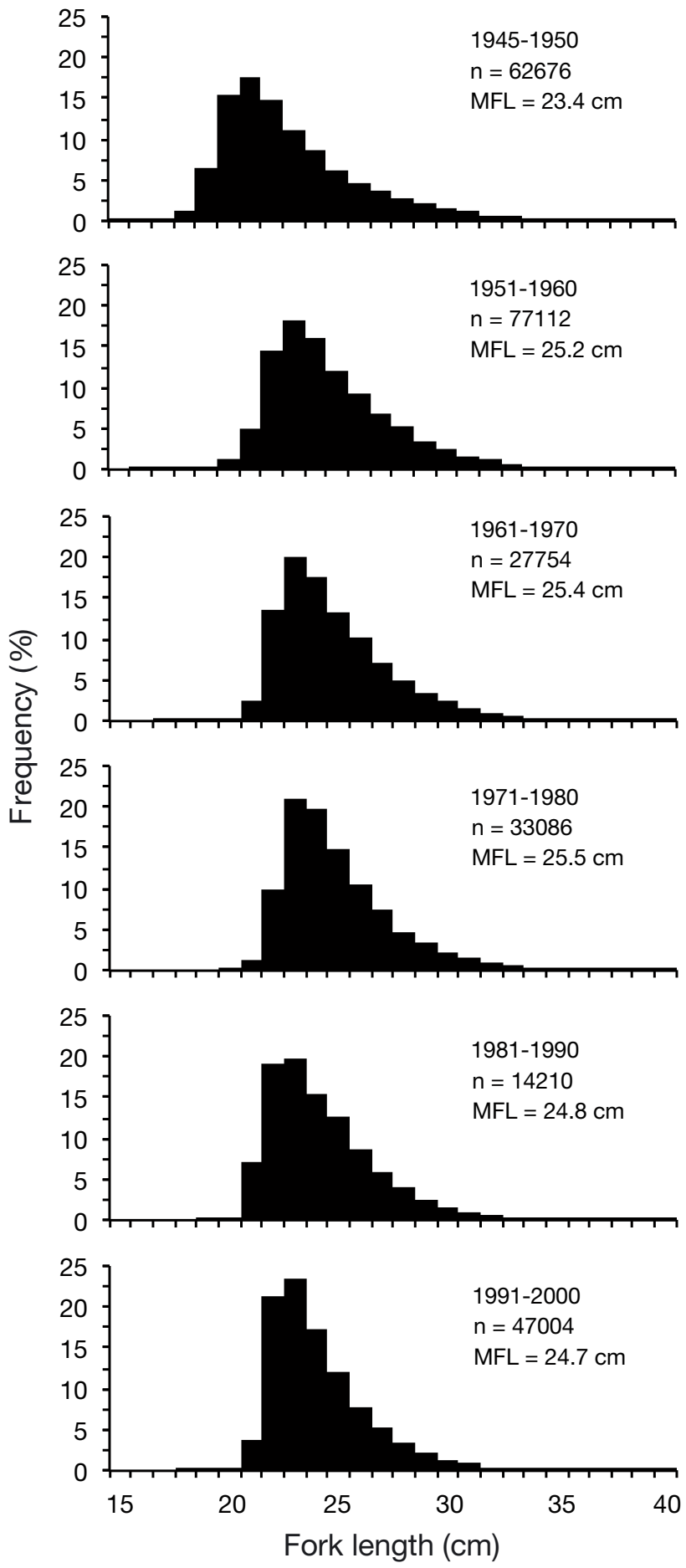

Fig. 9. Length compositions of retained catches of Acanthopagrus australis sampled at the Sydney Fish Market and regional cooperatives as part of the New South Wales Department of Primary Industries (NSW DPI) monitoring program between 1945 and 2000. n: sample size; MFL: mean fork length $(\mathrm{cm})$. The change in length composition between 1945 and 1950 and thereafter is attributed to the change in the minimum legal total length from 9 to 10 inches (22 to $25 \mathrm{~cm}$ TL; approximately 20 to $22.5 \mathrm{~cm}$ FL). Data are provided by the NSW DPI 
LM. Nevertheless, across all estuaries, $F$ was generally $>M$ and $E>0.5$, suggesting these populations were heavily fished. Despite this, estuary-specific differences in mortality schedules combined with differential age distributions could potentially lead to unique assessment outcomes and management scenarios for populations in each estuary.

Estuary-specific differences in age composition and longevity could also potentially impact species reproductive dynamics and population replenishment. The older females of several teleost species produce higher quality eggs and larvae, potentially enhancing population and fishery sustainability (Berkeley et al. 2004, Sogard et al. 2008). Although linkages among populations need to be considered in such assessments, this further highlights the importance of assessing age rather than length composition in examining potential fishery and other anthropogenic impacts on species population ecology.

The data presented here demonstrate that it is not valid to extrapolate results among estuaries or from one estuary to the entire A. australis population. Spatial variability in age-based demographic parameters of other exploited Sparidae is common (Vitale et al. 2011, Benchalel \& Kara 2013), with the observed variability in the derived demographic parameters of A. australis generally being greater among estuaries than among years within each estuary. Nevertheless, a greater time series of data is required to determine whether the patterns presented here persist temporally and represent a stable state and the natural condition of populations of $A$. australis in each estuary. Moreover, the rates of immigration and emigration and movements of $A$. australis among estuaries need to be quantified and considered in future assessments.

It could be argued that differences among estuaries in age compositions and rates of mortalities of A. australis reflected differences in harvests. The reported commercial harvest data do not support this hypothesis as despite $\mathrm{CR}$ having on average the greatest reported annual harvests and more than double the annual harvest of SGB, the population in CR consistently displayed the lowest rates of mortalities and had the greatest proportions of older fish in catches. Other factors, such as total available biomass and the quantity of the non-commercial harvest in each estuary, need to be considered in such examinations. The total recreational harvest of $A$. australis is generally assumed to be much greater than the total commercial harvest, with direct comparisons in several estuaries documenting this to be true (West \& Gordon 1994, Henry \& Lyle 2003, Rowling et al. 2010). LM and SGB are now closed to commercial fishing, with only recreational and indigenous take allowed. Clearly, the quantities and population demographics of the recreational and indigenous catch need to be considered in any future work investigating fishery impacts on A. australis.

\section{Consequences for population and fishery monitoring and assessment}

A common challenge facing management agencies is how to most efficiently and cost-effectively monitor and assess species taken in small-scale, multimethod and multi-sector fisheries. For A. australis, length is a poor indicator of age (see also Ochwada et al. 2008) and length composition cannot be used as a surrogate for age composition. This is also evident for other co-occurring species, notably G. tricuspidata (Gray et al. 2010). It would therefore be unwise to base an assessment program of such species on length alone, as potential spatial and temporal changes in important age-based demographic parameters required for assessments would not be detected.

Given the variable and spatially distinct lengthat-age relationships, separate age-length keys are required for each sampled estuary and year, which could be costly to obtain depending on the number of estuaries examined. Age-length keys should not be transferred among estuaries or years, as this would mask and confound potential spatial and temporal differences in age compositions and demography. This scenario may also apply to other medium- to long-lived estuarine and coastal teleost species that display spatially variable length-at-age relationships, such as Cynoscion nebulosus (Bedee et al. 2002), Epinephelus morio (Lombardi-Carlson et al. 2008) and G. tricuspidata (Gray et al. 2010, 2012). Whilst linear modeling that uses other covariates of age, such as otolith weight, sex and location, have potential use and may be more cost-effective than actual direct ageing of samples, they need to be tested and validated across appropriate spatial and temporal scales (Ochwada et al. 2008).

The variability observed here indicate that age compositions and rates of mortalities of $A$. australis would differ among other estuaries, and thus monitoring of only 1 or 2 estuaries as indicators of the entire $A$. australis population or fishery would not suffice. It is not feasible to sample every estuary, so it would be useful to know whether populations in estuaries located close together display more similar age compositions and demographic characteristics compared with populations in estuaries located at 
great distances. Sampling catches over a hierarchy of spatial scales across more than one year is required to test this hypothesis. Potentially, if the age compositions in nearby estuaries were most similar, then it may be possible to sample representative estuaries within a region to give an overview of the total population within that particular region.

For a more global assessment of the entire stock, an alternate option could involve stratifying sampling across a subset of estuaries according to expected catch (based on immediate past history). For example, the top 10 estuaries that make up over $50 \%$ of the total reported catch could be sampled to potentially provide a global population assessment. Such an approach, however, would not provide information on individual estuaries and may not provide management agencies with the required resolution of data required for assessing the performance of estuaries with different harvesting strategies. This would be particularly true for the many estuaries that permit only recreational and indigenous fishing.

There is a need to investigate the feasibility and cost-effectiveness of incorporating recreational catches as well as fishery-independent research surveys into sampling strategies for $A$. australis and other cooccurring exploited species to provide rigorous and standardized population assessments across the breadth of estuary management types. The data provided here can help develop suitable sampling strategies that ultimately need to be tailored to specific management questions.

Acknowledgements. Numerous colleagues, particularly Leeanne Raines and Vanessa Gale, at the (now closed) Cronulla Fisheries Research Centre of Excellence assisted with sampling, processing and ageing of samples, and managing sample collections in the field and at fishing cooperatives. Several colleagues, particularly Kevin Rowling, John Stewart, James Scandol, Geoff Liggins, Faith OchwadaDoyle, Rick Fletcher and Steve Kennelly, provided helpful discussions and critiques of the study and manuscript. The NSW Government and the Australian Fisheries Research and Development Corporation (project 94/042) provided funding for this research.

\section{LITERATURE CITED}

Abou-Seedo FS, Dadzie S, Al-Kanaan KA (2003) Sexuality, sex change and maturation patterns in the yellowfin seabream, Acanthopagrus latus (Teleostei: Sparidae) (Houttuyn, 1782). J Appl Ichthyol 19:65-73

Alós J, Palmer M, Alonso-Fernández A, Morales-Nin B (2010) Individual variability and sex-related differences in the growth of Diplodus annularis (Linnaeus, 1758). Fish Res 101:60-69

Anderson MJ (2001) A new method for non-parametric multivariate analysis of variance. Aust J Ecol 26:32-46

Babcock EA, Coleman R, Karnauskas M, Gibson J (2013) Length-based indicators of fishery and ecosystem status: Glover's Reef Marine Reserve, Belize. Fish Res 147: 434-445

Barnes LM, Gray CA, Williamson JE (2011) Divergence of the growth characteristics and longevity of coexisting Platycephalidae (Pisces). Mar Freshw Res 62:1308-1317

> Beamish RJ, McFarlane GA (1983) The forgotten requirement of age validation in fisheries biology. Trans Am Fish Soc 112:735-743

Bedee CD, DeVries DA, Bortone SA, Palmer CL (2002) Estuary-specific age and growth of spotted seatrout in the northern Gulf of Mexico. In: Bortone SA (ed) Biology of spotted sea trout. CRC Press, Boca Raton, FL, p 57-77

Begg GA, Campana SE, Fowler AJ, Suther IM (2005) Otolith research and application: current directions in innovation and implementation. Mar Freshw Res 56:477-483

Bell JD, Pollard DA, Burchmore JJ, Pease BC, Middleton MJ (1984) Structure of a fish community in a temperate tidal mangrove creek in Botany Bay, New South Wales. Aust J Mar Freshwater Res 35:33-46

Benchalel W, Kara MH (2013) Age, growth and reproduction of the white seabream Diplodus sargus sargus Linneaus, 1758) off the eastern coast of Algeria. J Appl Ichthyol 29: 64-70

Berkeley SA, Hixon MA, Larson RJ, Love MS (2004) Fisheries sustainability via protection of age structure and spatial distribution of fish populations. Fisheries 29:23-32

Broadhurst MK, Wooden MEL, Millar RB (2007) Isolating selection mechanisms in beach seines. Fish Res 88:56-69

Brouwer SL, Griffiths MH (2004) Age and growth of Argyrozona argyrozona (Pisces: Sparidae) in a marine protected area: an evaluation of methods based on whole otoliths, sectioned otoliths and mark-recapture. Fish Res 67:1-12

Buxton CD (1993) Life-history changes in exploited reef fishes on the east coast of South Africa. Environ Biol Fishes 36:47-63

Buxton CD, Garratt PA (1990) Alternative reproductive styles in seabreams (Pisces: Sparidae). Environ Biol Fishes 28:113-124

> Campana SE (2001) Accuracy, precision and quality control in age determination, including a review of the use and abuse of age validation methods. J Fish Biol 59:197-242

Choat JH, Robertson DRR (2002) Age-based studies. In: Sale $\mathrm{PF}$ (ed) Coral reef fishes: dynamics and diversity in a complex ecosystem. Elsevier Science, San Diego, CA, p 57-80

Clarke KR (1993) Nonparametric multivariate analyses of changes in community structure. Aust J Ecol 18:117-143

Doubleday WG, Rivard D (1983) Sampling commercial catches of marine fish and invertebrates. Canadian Special Publications of Fisheries and Aquatic Sciences 66

Dulčić J, Pallaoro A, Matić-Skoko S, Dragičević B and others (2011) Age, growth and mortality of common twobanded seabream, Diplodus vulgaris (Geoffroy SaintHilaire, 1817), in the eastern Adriatic Sea (Croatian coast). J Appl Ichthyol 27:1254-1258

Ferrell JD (2000) Validation of annual ageing and sources of ageing error in 4 coastal marine finfish from NSW. In: Gray CA, Pease BC, Stringfellow SL, Raines LP, Rankin BK, Walford TR (eds) Sampling estuarine fish species for stock assessment. NSW Fisheries Final Report Series, No. 18. NSW Government, Cronulla, p 147-154

Fowler AJ, Short DA (1998) Validation of age determination 
from otoliths of the King George whiting Sillaginodes punctata (Perciformes). Mar Biol 130:577-587

Gonçalves JMS, Bentes L, Coelho R, Correia C and others (2003) Age and growth, maturity, mortality and yieldper-recruit for two banded bream (Diplodus vulgaris Geoffr.) from the south coast of Portugal. Fish Res 62: 349-359

> Grandcourt EM, Al Abdessalaam TZ, Francis F, Al Shamsi AT (2004) Biology and stock assessment of the sparids, Acanthopagrus bifasciatus and Argyrops spinifer (Forsskål, 1775), in the Southern Arabian Gulf. Fish Res 69: $7-20$

> Gray CA (2002) Management implications of discarding in an estuarine multi-species gill net fishery. Fish Res 56: 177-192

Gray CA, Kennelly SJ (2003) Catch characteristics of the commercial beach-seine fisheries in two Australian barrier estuaries. Fish Res 63:405-422

Gray CA, McElligott DM, Chick RW (1996) Intra- and interestuary differences in assemblages of fishes associated with shallow seagrass and bare sand. Mar Freshw Res 47:723-735

Gray CA, Pease BC, Stringfellow SL, Raines LP, Rankin BK, Walford TR (2000) Sampling estuarine fish species for stock assessment. NSW Fisheries Final Report Series, No. 18. NSW Government, Cronulla

> Gray CA, Gale VJ, Stringfellow SL, Raines LP (2002) Variations in sex, length and age compositions of commercial catches of Platycephalus fuscus (Pisces: Platycephalidae) in New South Wales, Australia. Mar Freshw Res 53: 1091-1100

> Gray CA, Johnson DD, Broadhurst MK, Young D (2005) Seasonal, spatial and gear-related influences on relationships between retained and discarded catches in a multispecies gillnet fishery. Fish Res 75:56-72

- Gray CA, Ives MC, Macbeth WG, Kendall BW (2010) Variation in growth, mortality, length and age compositions of harvested populations of the herbivorous fish, Girella tricuspidata. J Fish Biol 76:880-899

> Gray CA, Haddy JA, Fearman J, Barnes LM, Macbeth WG, Kendall BW (2012) Reproduction, growth and connectivity among populations of Girella tricuspidata (Pisces: Girellidae). Aquat Biol 16:53-68

Gray CA, Barnes LM, Ochwada-Doyle FA, van der Meulen DE, Kendall BW, Robbins WD (2014) Age, growth and demographic characteristics of Sillago flindersi exploited in a multi-species trawl fishery. Fish Sci 80:915-924

$>$ Griffiths SP (2001) Recruitment and growth of juvenile yellowfin bream, Acanthopagrus australis Gunther (Sparidae), in an Australian intermittently open estuary. J Appl Ichthyol 17:240-243

Gust N, Choat JH, Ackerman JL (2002) Demographic plasticity in tropical reef fishes. Mar Biol 140:1039-1051

Heibo E, Magnhagen C, Vøllestad LA (2005) Latitudinal variation in life-history traits in Eurasian perch. Ecology 86:3377-3386

Henry GW, Lyle JM (2003) The national recreational and indigenous fishing survey. Final report to the Fisheries Research \& Development Corporation, Project 99/158. NSW Fisheries Final Report Series No. 48. NSW Government, Cronulla

Hilborn R, Walters CJ (1992) Quantitative fisheries stock assessment: choice, dynamics and uncertainty. Chapman \& Hall, New York, NY

Hoenig JM (1983) Empirical use of longevity data to esti- mate mortality rates. Fish Bull 82:898-902

> Horn PL (1986) Distribution and growth of snapper Chrysophrys auratus in the North Taranaki Bight, and management implications of these data. N Z J Mar Freshw Res 20:419-430

Hughes JM, Stewart J, Kendall BW, Gray CA (2008) Growth and reproductive biology of tarwhine Rhabdosargus sarba (Sparidae) in eastern Australia. Mar Freshw Res 59:1111-1123

Kailola PJ, Williams MJ, Stewart PC, Reichelt RE, McNee A, Grieve C (1993) Australian fisheries resources. Bureau of Resource Sciences, Canberra

Kendall BW, Gray CA (2009) Reproduction, age and growth of Sillago maculata (Sillaginidae) in south-eastern Australia. J Appl Ichthyol 25:529-536

Kendall BW, Gray CA, Bucher DD (2009) Age validation and variation in growth, mortality and population structure of Liza argentea and Myxus elongatus (Mugilidae) in two temperate Australian estuaries. J Fish Biol 75:2788-2804

Kingsford MJ (2002) The distribution patterns of exploited girellid, kyphosid and sparid fishes on temperate rocky reefs in New South Wales, Australia. Fish Sci 68(Suppl I): 131-134

Lai H, Gallucci VF, Gunderson DR, Donnelly RF (1996) Age determination in fisheries: methods and applications to stock assessment. In: Gallucci VF, Saila SB, Gustafson DJ, Rothschild BJ (eds) Stock assessment: quantitative methods and applications for small-scale fisheries. CRC Lewis Publishers, New York, p 82-178

> Lombardi-Carlson L, Fitzhugh G, Palmer C, Gardner C, Farsky R, Ortiz M (2008) Regional size, age and growth differences of red grouper (Epinephelus morio) along the west coast of Florida. Fish Res 91:239-251

- Marriott RJ, Adams DJ, Jarvis NDC, Moran MJ, Newman SJ, Craine M (2011) Age-based demographic assessment of fished stocks of Lethrinus nebulosus in the Gascoyne Bioregion of Western Australia. Fish Manag Ecol 18: 89-103

Meekan MG, Ackerman JL, Wellington GM (2001) Demography and age structures of coral reef damselfishes in the tropical eastern Pacific Ocean. Mar Ecol Prog Ser 212:223-232

> Morison A, Coutin P, Robertson S (1998) Age determination of black bream, Acanthopagrus butcheri (Sparidae) from the Gippsland Lakes of south-eastern Australia indicates slow growth and episodic recruitment. Mar Freshw Res 49:491-498

> Newman SJ, Williams DMcB, Russ GR (1996) Age validation, growth and mortality rates of the tropical snappers (Pisces: Lutjanidae), Lutjanus adetii (Castelnau, 1873) and L. quinquelineatus (Bloch, 1790) from the central Great Barrier Reef, Australia. Mar Freshw Res 47:575-584

$>$ Newman SJ, Cappo M, Williams DMcB (2000) Age, growth, mortality rates and corresponding yield estimates using otoliths of the tropical red snappers, Lutjanus erythropterus, L. malabaricus and L. sebae, from the central Great Barrier Reef. Fish Res 48:1-14

> Ochwada FA, Scandol JP, Gray CA (2008) Predicting the age of fish using general and generalized linear models of biometric data: a case study of two estuarine finfish from New South Wales, Australia. Fish Res 90:187-197

Pajuelo JG, Lorenzo JM (2000) Reproduction, age, growth and mortality of axillary seabream, Pagellus acarne (Sparidae), from the Canarian archipelago. J Appl Ichthyol 16:41-47 
Pajuelo JG, Lorenzo JM (2003) The growth of the common two-banded seabream, Diplodus vulgaris (Teleostei, Sparidae), in Canarian waters, estimated by reading otoliths and by back-calculation. J Appl Ichthyol 19:79-83

> Pajuelo JG, Lorenzo JM (2004) Basic characteristics of the population dynamic and state of exploitation of Moroccan white seabream Diplodus sargus cadenati (Sparidae) in the Canarian archipelago. J Appl Ichthyol 20:15-21

Pajuelo JG, Martínez I, González JA, Lorenzo JM, GarcíaMederos A, Domínguez-Seoane R, Hernández-Cruz CM (2006) Growth pattern and age estimation of the coastal sparid fish Pagrus auriga on the Canary Islands shelf. Fish Res 82:7-13

Patterson K, Cook R, Darby C, Gavaris S and others (2001) Estimating uncertainty in fish stock assessment and forecasting. Fish Fish 2:125-157

Pollock BR (1982) Spawning period and growth of yellowfin bream, Acanthopagrus australis (Günther), in Moreton Bay, Australia. J Fish Biol 21:349-355

Pollock BR (1985) The reproductive cycle of yellowfin bream, Acanthopagrus australis (Günther), with particular reference to protandrous sex inversion. J Fish Biol 26: 301-311

Quinn TJ, Deriso RB (1999) Quantitative fish dynamics. Oxford University Press, New York, NY

Ricker WE (1975) Computation and interpretation of biological statistics of fish populations. Bulletin of the Fisheries Research Board of Canada 191

Rowling K, Hegarty A, Ives MC (2010) Status of fisheries resources in NSW 2008/09. Industry and Investment NSW, Cronulla

Ruttenberg BI, Haupt AJ, Chiriboga AI, Warner RR (2005) Patterns, causes and consequences of regional variation in the ecology and life history of a reef fish. Oecologia 145:394-403

Sala-Bozano M, Mariani S (2011) Life history variation in a marine teleost across a heterogeneous seascape. Estuar Coast Shelf Sci 92:555-563

Sarre GA, Potter IC (2000) Variation in age composition and growth rates of Acanthopagrus butcheri (Sparidae) among estuaries: some possible contributing factors. Fish Bull 98:785-799

Silberschneider V, Gray CA, Stewart J (2009) Age, growth, maturity and the overfishing of the iconic sciaenid, Argyrosomus japonicus, in south-eastern Australia. Fish Res 95:220-229

Sinclair AF, Swain DP, Hanson JM (2002) Disentangling the effects of size-selective mortality, density, and temperature on length-at-age. Can J Fish Aquat Sci 59:372-382

Smale MJ, Punt AE (1991) Age and growth of the red steen-

Editorial responsibility: Christine Paetzold, Oldendorf/Luhe, Germany bras Petrus rupestris (Pisces:Sparidae) on the south-east coast of South Africa. S Afr J Mar Sci 10:131-139

Smith KA, Deguara K (2003) Formation and annual periodicity of opaque zones in sagittal otoliths of Mugil cephalus (Pisces: Mugilidae). Mar Freshw Res 54:57-67

Sogard SM, Berkeley SA, Fischer R (2008) Maternal effects in rockfishes Sebastes spp.: a comparison among species. Mar Ecol Prog Ser 360:227-236

Stewart J (2011) Evidence of age-class truncation in some exploited marine fish populations in New South Wales, Australia. Fish Res 108:209-213

> Stewart J, Hughes JM (2009) Biological and fishery characteristics of rubberlip morwong Nemadactylus douglasii (Hector, 1875) in eastern Australia. Fish Res 96:267-274

> Stocks J, Gray CA, Taylor MD (2014) Synchrony and variation across latitudinal gradients: the role of climate and oceanographic processes in the growth of a herbivorous fish. J Sea Res 90:23-32

> Vila-Gispert A, Moreno-Amich R, Garcia-Berthou E (2002) Gradients of life-history variation: an intercontinental comparison of fishes. Rev Fish Biol Fish 12:417-427

> Vitale S, Arkhipkin A, Cannizzaro L, Scalisi M (2011) Life history traits of the striped seabream Lithognathus mormyrus (Pisces, Sparidae) from two coastal fishing grounds in the Strait of Sicily. J Appl Ichthyol 27:1086-1094

Walsh CT, Gray CA, West RJ, van Der Meulen DE, Williams LFG (2010) Growth, episodic recruitment and age truncation in populations of a catadromous percichthyid, Macquaria colonorum. Mar Freshw Res 61:397-407

Walters CJ, Martell SJD (2004) Fisheries ecology and management. Princeton University Press, Princeton, NJ

West RJ, Gordon G (1994) The commercial and recreational harvest of fish from two Australian coastal rivers. Aust J Mar Freshw Res 45:1259-1279

Williams AJ, Davies CR, Mapstone BD, Russ GR (2003) Scales of spatial variation in demography of a large coral reef fish: an exception to the typical model? Fish Bull 101: 673-683

Williams AJ, Mapstone BD, Davies CR (2007) Spatial and interannual patterns in growth of an exploited coral-reef fish. J Fish Biol 71:970-992

- Williams AJ, Davies CR, Mapstone BD, Currey LM and others (2009) Age-based demography of humpback grouper Cromileptes altivelis: implications for fisheries management and conservation. Endang Species Res 9: $67-79$

Worthington DG, Ferrell DJ, McNeill SE, Bell JD (1992) Growth of four species of juvenile fish associated with the seagrass Zostera capricorni in Botany Bay, New South Wales. Aust J Mar Freshw Res 43:1189-1198

Submitted: July 3, 2014; Accepted: January 28, 2015

Proofs received from author(s): February 15, 2015 